Patheneni Sivaswaroop:

\title{
The Internet and Hinduism - A Study
}

\begin{abstract}
:
This paper discusses some results of a sample study on how Hindus are using the internet for religious purposes comparing their on-line and off-line religious activities. The behaviour is similar to those reported for different religions from different countries. But it is found that $74 \%$ of the sample pray daily, where only $16 \%$ go daily to a local temple. This seems to be a major difference between Western and the Hindu religions. In Hinduism going to temple is secondary, as each Hindu house has generally a pooja (room/corner). The survey reports and the uses of the internet by Hindus as well as whether the internet increases religious tolerance or hatred.
\end{abstract}

\section{Agenda:}

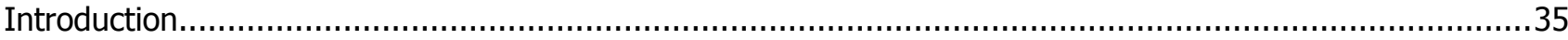

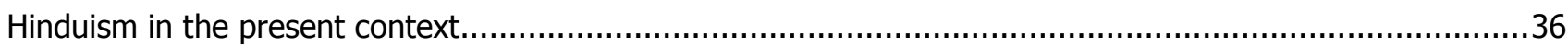

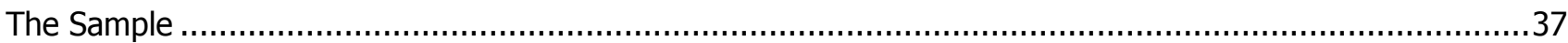

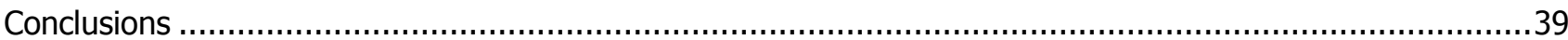

Author:

Dr P. Sivaswaroop, Deputy Director

- Regional Centre, Indira Gandhi National Open University, Himayat Nagar, Hyderabad - 500 029. India.

- . 0091-9885030060; $\square$ psivaswaroop@yahoo.com

- Relevant Publications:

- Resilience of Ethics and Values in Higher Education - Pre requisite for providing Value Orientation, University News (Special Issue on "Engagement of Universities with Society") 43 (02) 2005, 13-16.

- Educational Ethics: Need of the Hour, University News (Special Issue on "Private Participation in Indian Higher Education :Contemporary issues and Challenges" 42 (07) 2004. 72-75. 


\section{Introduction}

The lost tribes in biblical times saw God as a column of smoke or a pillar of fire. When kings and emperors emerged on the world scene, people imagined God as a King on a distant throne. In Hinduism, it is believed that God expressed himself in different forms of nature like fire, water, sun, moon, etc. In Lord Vishnu's Dasavataras, the Lord took the forms of different living beings like Matsya (the fish), Kurma (the tortoise), Varaha (the boar), Rama and Krishna (the form of human beings), etc. Each avatara was for a specific purpose in those times. Even today Hindus pray to different living beings on specific days like snakes on Naga Panchami, cattle on Pongal, etc. Thus the system refers to worshipping nature, as if God is being manifested in different forms. Even some depict God as Nirakara (without shape). As such some scholars state that there is no unique single/supreme God in Hinduism, even though different sects believe that their manifestation of God in that particular form is supreme.

In the present day certain cutting-edge religious scholars are likening the internet to as a space where the Divine resides. Some state that the internet serves as an "important way station" on humanity's journey towards a greater spiritual evolution. ${ }^{96}$ A Hindu website states "Hindus use any form of worship available (... ) Why not then use the Internet as another venue of worship? ${ }^{\prime \prime 7}$ Thus it appears that different religions are propagating their own theories using the web as an appropriate medium for spreading their own religions. As a consequence, the present trend shows that almost all religions have extended their presence in the "Cyber World". ${ }^{8}$

Charles Ess has done extensive work on religions and the internet. He reported that mainline religious websites functioned as static repositories of

\footnotetext{
96 Jennifer Cobb in Cybergrace as referred in Campbell (2005).

97 Jacobs (2007).
98 Helland (2004).
}

texts, whereas others use in a more interactive way to actively engage potential converts with online forums, chats, etc. In initial stages of "cyber-religion," it was felt that "the authoritarian belief in religions will weaken and with availability on internet will lead to egalitarianism in religious matters. But the so far experience proved it wrong and "cyber-religion" is strengthening the existing religious system (Larsen, 2007)." 99 Ess has also stated that the technology has made the world a small 'global village' but that this phrase has been replaced with "global city" reflecting the modern metropolis life style of an ethnic neighbourhood. The internet has become so interwoven with daily life, especially in the developed world, that it has become a true mirror of daily life. So real world conflicts also are manifested on the internet as well.

With the advent of computers they were found to be a convenient and labour saving. But now with advances in technology, they have become a life transforming experience. ${ }^{100}$ It was reported that when memorial services were provided online, it appears that the internet was not only good for collaborative working, but also for building communities. It was also reported that a prayer meeting in the virtual world may not provide the same type of religious experience as a conventional church service, but it certainly reproduces some of the essential features of the latter albeit in novel ways. ${ }^{101}$

Helland reports that $78 \%$ of religious websites are Christian. ${ }^{102}$ But their usefulness depends on the spread of Information and Communication Technologies (ICTs) in a particular geographical location. Many Asian churches are working among poor and marginalised, with lack of electricity and inadequate access to modern technologies. But ICTs are moving forward and bringing down costs, making communication tools affordable and accessible to an increasing number of people. The $6^{\text {th }}$

\footnotetext{
99 Ess (2007a).

100 Henderson (2002).

${ }^{101}$ Schroeder et. al. (1998).

102 Helland (2004).
} 
Bishop's Institute for Social Communication was held on June 2007 in Bangkok. The 'Orientation and Recommendations' made by this BISCOM VI state that the people matter the most, more than the technology. One should promote any ways and means to preserve the cultural identity and at the same time try also to integrate them into the new communication situation. The traditional means of face-to-face communications as well as the use of folk media and radio still have widest reach and importance at the lowest cost. ${ }^{103}$

\section{Hinduism in the present context}

The Indian metropolitan cities, like other metro cities elsewhere, are immigrant territories with people from different cultures staying together. Immigrants attempt to preserve elements of what they have left behind while assimilating the new. They desire to re-create a lost group identity, as they are away from their native places. Technology can assist them in meeting their requirement. Also in the present day intense competitive world, individuals seek spiritual anchorage for a solace. The internet gives an avenue for this. ${ }^{104}$ The cyber darshan of deities is an example. Sood indicates that it may not be strange to see Hindu houses in the future with computers in their pooja rooms, so that they can watch or participate in the online pooja of any chosen deity of a famous temple. ${ }^{105}$

But according to the traditional Hindu culture, the main deity (Moola Viraat) is not allowed to be photographed or video-graphed. So there is a culture of simulating the famous temples and also the religious theme parks have come into being. ${ }^{106}$

There are several websites offering options to people. For example virtualtemples. $\mathrm{Com}^{107}$ is about Hindu temples through which one can visit temples virtually. There are sites which offer various

\footnotetext{
${ }^{103}$ FABC (2007).

${ }^{104}$ Hoskote (2006).

${ }^{105}$ Sood (2000).

${ }^{106}$ Hoskote (2006).

107 http://www.virtualtemples.com
}

stotras (prayers) to different gods. ${ }^{108}$ Through these, one can practice the bhajans and prayers.

Whereas the websites of ancient temples like Tirumala Tirupati Devasthanam (TTD) at Tirupati in South India do not give live darshan, as cameras are not allowed inside the Sanctum Sanctorum of any traditional Hindu temple, it is reported that Tirupati is the most visited place of the World, with around 50-100 thousand people visiting a day. The total visitors last year was around 19 million. ${ }^{109}$ The temple's website gives information about darshan timings, special poojas, accommodation availability in guest houses, etc. ${ }^{110}$

Shirdi Sai Baba at Shirdi in West India is a shrine of recent origin (in $20^{\text {th }}$ Century), where the deity of Shirdi Sai Baba is available for online darshan. ${ }^{111}$ The live darshan is made available through the web and selected TV Channels. Its website also gives information about accommodation etc. Still, the number of pilgrims visiting the shrine is also very high (around 25,000 a day). Even the web site visitors of Shirdi Sai Baba Temple number around 2.5 million as recently as June 2008.

This underlines that nowadays people are following their beliefs according to their convenience. They might feel that is always good to go to a temple and mingle with people of like faith, but perhaps it is not wrong to watch a pooja online. Cyber worship does not need to replace real worship. Hindu tradition says that devotion is more important than the methods or procedures. Whether one has offered pooja luxuriously or in a simple manner has no religious significance. Devotion or bhakt is of primary importance. The submission or purity of inner soul or atma is more crucial than the outward exhibitions. Therefore these cyber darshans, on-line information, replica of temples can help people to sustain their religious faith rather than replacing it. The increasing number of pilgrims to temples substantiate the increasing faith in religion. Is it reflecting that people are basically religious at their heart, but

\footnotetext{
${ }^{108}$ e.g. http://telugubhakti.com

${ }^{109}$ NDTV (2007).

${ }^{110}$ www.tirumala.org

${ }^{111}$ www.shrisaibabasansthan.org
} 
their busy life styles make them turn to Cyber or TV darshans?

There are several studies on usage of the internet among different religions. ${ }^{112}$ Following these studies this paper provides a sample study aiming to analyze how the internet is used among Hindus for religious purposes and what their objectives are, how they view the internet, how frequently they perform pooja, etc.

\section{The Sample}

Indira Gandhi National Open University (IGNOU) is the leading Open and Distance Learning (ODL) institute in India with 1.8 million students. They encompass a wide spectrum of sociological, economic, or cultural backgrounds. There are students from 18 years to 84 years, rural, unemployed youth to urban, highly paid professionals. In brief, the IGNOU learners represent a true cross section of society.

The sample comprises the IGNOU learners pursuing at two South Indian cities, namely Hyderabad (Metropolitan City) and Visakhapatnam (City). As far as the internet is a modern technology, care is taken that only graduates who can use this technology are taken as sample. The sample learners include those who are pursuing Master in Computer Applications (MCA) and Bachelor of Education (B.Ed). Very few respondents are from other cities and few Non-Resident Indians.

The demographic characteristics of the sample are as follows: The samples size is 185.

- Usage of the internet: $60 \%$ of the respondents said that they use the internet at least weekly once including $35 \%$, who use it daily, $8 \%$ said they never use internet.

- Performing Pooja: $86 \%$ of the respondents replied that they perform pooja/pray to God at least weekly once, including $74 \%$ who are praying daily. $11 \%$ said they pray occasionnally. It was reported that in USA, $86 \%$ of religion surfers pray daily as against $23 \%$ of all Americans. http://jmm.aaa.net.au/articles/9782.ht m

- $\quad$ Physical visits to temples. The following table gives data on the physical visit to a local temple and pilgrimage to a famous holy temple. Thus, nearly $3 / 5^{\text {th }}$ of the sample are under 30 years

\begin{tabular}{|c|c|c|}
\hline No. & Character & $\begin{array}{l}\text { Percent- } \\
\text { age }\end{array}$ \\
\hline 1 & $\begin{array}{l}\text { Gender } \\
\text { a) Male } \\
\text { b) Female }\end{array}$ & $\begin{array}{l}56 \\
44\end{array}$ \\
\hline 2 & $\begin{array}{l}\text { Age Group: } \\
\begin{array}{l}\text { a) } 21-30 \\
\text { b) } 31-40 \\
\text { c) } 41-60\end{array}\end{array}$ & $\begin{array}{l}58 \\
35 \\
07\end{array}$ \\
\hline 3 & $\begin{array}{l}\text { Highest Education Qualifi- } \\
\text { cation } \\
\text { a) Graduate } \\
\text { b) Post Graduate } \\
\text { c) PhD }\end{array}$ & $\begin{array}{l}48 \\
50 \\
02\end{array}$ \\
\hline 4 & $\begin{array}{l}\text { Employment Status } \\
\text { a) Employed } \\
\text { b) Unemployed }\end{array}$ & $\begin{array}{l}77 \\
23\end{array}$ \\
\hline \multirow[b]{2}{*}{5} & $\begin{array}{l}\text { Total length of Service for } \\
\text { employed (in years) }\end{array}$ & \\
\hline & $\begin{array}{ll}\text { a) } & 1-5 \\
\text { b) } & 6-10 \\
\text { c) } & 11-15 \\
\text { d) } & 16-20 \\
\text { e) } & 21-25\end{array}$ & $\begin{array}{l}45 \\
34 \\
10 \\
06 \\
05\end{array}$ \\
\hline
\end{tabular}

age. Men and women are nearly distributed. $77 \%$ or $3 / 4^{\text {th }}$ of sample are employed.

112 Bell (2004), Ess (2007b), Kluver and Cheong, (2007), Jacobs (2007). 


\begin{tabular}{|c|c|c|}
\hline S. No. & Parameter & Percentage \\
\hline 1 & $\begin{array}{l}\text { How frequently do you } \\
\text { perform pooja? } \\
\text { a) Daily } \\
\text { b) Weekly } \\
\text { c) Monthly } \\
\text { d) Occasionally } \\
\text { e) Never }\end{array}$ & $\begin{array}{l}74 \\
12 \\
02 \\
11 \\
01\end{array}$ \\
\hline 2 & $\begin{array}{l}\text { How frequently do you } \\
\text { visit a local temple? } \\
\text { a) Daily } \\
\text { b) Weekly } \\
\text { c) Monthly } \\
\text { d) Occasionally } \\
\text { e) Never }\end{array}$ & $\begin{array}{l}16 \\
40 \\
15 \\
35 \\
01\end{array}$ \\
\hline 3 & $\begin{array}{l}\text { How frequently do you } \\
\text { go on pilgrimage? } \\
\text { a) Frequently } \\
\text { b) Occasionally } \\
\text { c) Rarely } \\
\text { d) Never }\end{array}$ & $\begin{array}{l}16 \\
48 \\
23 \\
13\end{array}$ \\
\hline
\end{tabular}

The figures above reflect that $74 \%$ of the respondents perform pooja daily, but only $16 \%$ of them are going to temple daily and $16 \%$ are going on pilgrimage frequently. It seems to be that the religiosity is very personal and individualistic and they may not find time to go to temple daily. In Hindu customs, a particular day in a week is specified for a particular God like Thursday for Shirdi Saibaba, Saturday for Sri Venkateswara Swamy etc. The devotees of particular Gods visit the corresponding temples on those week days. $40 \%$ of the sample visiting temples weekly once, reflect this tradition. This confirms the statement of the Web designer of Hindu Virtual Temple that "in Hinduism, going to a Temple is often considered to be secondary to domestic worship and many Hindus have a cupboard, a corner or a room that is dedicated shrine." ${ }^{1}$

Religious information through the internet: Asked if they get any religious information on the internet the responses from the sample are equally divided in affirmation (49\%) and negation (51\%).

${ }^{1}$ Jacobs (2007)
Among all US Citizens, $25 \%$ of internet users get religious information 'on line' at one point or another. $^{2}$

Type of information from the internet. They are asked to respond to what type of information they get from the internet and are free to choose as many as appropriate, from the seven possible given options. The responses in the order of ranking are as follows:

The first ranking response was that the respondents refer to the internet for studying religious philosophy. In a way, it resembles the US studies which reported that most religion surfers use the internet as a library and search for general spiritual information. ${ }^{3}$

Live darshan and email usage: Only $18 \%$ of the respondents said that they watch any 'Live darshan' of Deities on the internet. A similar low level response $(13 \%)$ was received about whether they sought any religious advice using e-mail. These reflect the less popularity of these aspects among the sample. As it is reported in USA $28 \%$ of the users have searched for religious advice through internet/email. ${ }^{4}$

The internet supplementing religion: $61 \%$ respondents accepted that internet is a supplementary tool for their religious commitment. Larsen also had the same conclusion based on PEW Internet and American Life Project Results. ${ }^{5} 76 \%$ of the respondents agreed moderately to strongly that the internet is helping people to learn about their religion. $65 \%$ felt that the internet is helping to spread their religion across the Globe. And 80\% accepted that the internet is helping non-resident people (in India) to keep in touch with their native cultures.

Hence a majority of respondents have positive opinion on the Internet as being useful for religious issues. The religious leaders of different

\footnotetext{
${ }^{2}$ http://jmm.aaa.net.au/articles/9782.htm

${ }^{3}$ http://jmm.aaa.net.au/articles/9782.htm

${ }^{4}$ Henderson (2002).

${ }^{5}$ Larsen (2007).
} 


\begin{tabular}{|c|l|c|}
\hline Ranking & \multicolumn{1}{|c|}{ Parameter } & $\begin{array}{c}\text { Percentage of those } \\
\text { who get religious in- } \\
\text { formation from the } \\
\text { internet }\end{array}$ \\
\hline I & $\begin{array}{l}\text { About Religious Philoso- } \\
\text { phy }\end{array}$ & 69 \\
\hline II & About Pilgrim centre & 67 \\
\hline III & $\begin{array}{l}\text { Accommodation availabi- } \\
\text { lity and Booking }\end{array}$ & 63 \\
\hline IV & Timing of Darshan & 61 \\
\hline V & About God & 58 \\
\hline VI & Booking of Pooja & 53 \\
\hline VII & $\begin{array}{l}\text { About availability of } \\
\text { Darshan }\end{array}$ & 48 \\
\hline VIII & $\begin{array}{l}\text { All Seven options res- } \\
\text { ponded }\end{array}$ & 23 \\
\hline
\end{tabular}

expressed by the religious leaders in Singapore. ${ }^{9}$ It reflects that the internet is not regarded as a foreign, imported technology. Its negative effects are less worrying the sample.

Among the sample, daily pooja performing Group and Female Group are checked for any deviant behaviour from the whole Sample. In sum they share the same opinions except a few as follows:

1. For going on pilgrimage, the general sample showed that $48 \%$ go 'occasionally', whereas the majority of these two specific Groups go 'rarely' to pilgrimage.

religions in Singapore had a broad based acceptance for the Internet. ${ }^{6}$

The internet and religious tolerance/hatred: Asked if the internet will increase religious tolerance or hatred, the responses are surprisingly same for both issues. $60 \%$ felt the internet encourages tolerance. Surprisingly even among US Citizens, $62 \%$ felt that the availability of material on internet encourages religious tolerance. ${ }^{7}$ Whereas $55 \%$ of the present sample felt that the internet may be misused for increasing religious hatred. It reflects that respondents of this sample are of equal opinion on both the positive and negative effects of the Internet on inter-religious issues.

The internet as a source of immoral content. Surprisingly, $63 \%$ negated the opinion that the internet is a danger for being source for immoral content. So they see internet as a positive tool. In Kluver and Cheong's study, ${ }^{8}$ some of the religious leaders saw a danger of immoral content from the internet. The present sample of common citizens, express less concern on this negative aspect of the internet. Also when asked about whether the internet is viewed as an imposition from the Western world, $60 \%$ said ' $N \mathrm{No}^{\prime}$. A similar view was

\footnotetext{
${ }^{6}$ Kluver and Cheong (2007).

${ }^{7}$ Larsen (2007).

${ }^{8}$ Kluver and Cheong (2007).
}

2. The first ranking information on the internet for these groups is:

a. for daily pooja group, it is 'about Pilgrim Centres'

b. for female group, it is 'accommodation availability', perhaps they prefer family comfort during the pilgrimage.

\section{Conclusions}

The sample study leads us to the following conclusions:

1. $86 \%$ and $60 \%$ respondents perform pooja and use the internet at least once a week.

\section{2. $56 \%$ visit local temple at least once a week.}

3. $50 \%$ use the internet for religious information. The majority use it for religious philosophy and getting information on pilgrim centres visit etc.

4. Live darshar' watching and seeking religious advice through e-mail are less popular.

5. The majority agree that the internet is supplementing religion.

6. Respondents are undecided if the internet increases religious tolerance or hatred.

\footnotetext{
${ }^{9}$ Kluver and Cheong (2007).
} 
This small sample study has shown that the internet is accepted and it is used for religious purposes by Hindus. But due to traditional and ICT limitations, its use is limited. Furthermore the internet is rather supplementing than replacing the real religious practices of daily pooja, visit to temples etc. Perhaps in the future we may see an increasing interwovening of the internet and of Hindu religion.

\section{References}

Bell, Genevieve: Getting to God: Technology, Religion and the New Enlightenment. IFTF's Future Now, 26 ${ }^{\text {th }}$ August 2004. http://future.iftf.org/2004/08/genevive bell g. html

Campbell, Heidi : 'Spiritualising the Internet: Uncovering Discourses and narratives of Religious Internet usage' Heidelberg Journal of Religions on the Internet, 2005. http://archiv.ub.ubi-

heidel-

berg.de/volltextserver/volltexte/2005/5824/pdf

Ess, Charles: "War and Peace, East and West Online: A Comparison of How Different World Religions Use the Internet". 2007a. http://www.ht.ntnu.no/cofu/content/charles\% 20ess.\$d\$). RNo.13

Ess, Charles, Kawabata $A$ and Kurosaki, H: 'Cross Cultural Perspectives on Religion and Computer Mediated Communication, Journal of Computer Mediated Communication, 2007b. 12(3).

http://jcmc.indiana.edu/vol12/issue3/ess.html

FABC OSC: "Sixth "Bishops' Institute for Social Communication" (BISCOM VI) "Converging Communications for Ministry in Asia: Modern Communication Technologies for the Church", Bangkok, Thailand, May 28 June, 2007. Vol. XXII, No. 6, June, 2007.

http://www.fabc.org/offices/osc/docs/newsletters/ INFO June 07.pdf). RNo.5

Helland, Christopher: 'Popular religion and the World web ' in L Dawson \& D Cowan (Eds.).: Religion online: Finding Faith on the Internet 2004. London and New York: Routledge, pp. 34-36.

Henderson, Charles: "Religion and the Internet" at MIT's Communication Forum, April $18^{\text {th }}$ 2002. http://web.mit.edu/commforum/forums/religion.html).
Hoskote, Ranjit: "Miracle Moments, Virtual Shrines", Date: 17/09/2006, The Hindu News Paper.

(http://thehindu.com/thehindu/mag/2006/09/ 17/stories/2006091700370100.htm

Jacobs, Stephen: "Virtually Sacred: The Performance of Asynchronous Cyber Rituals in Online Spaces" Journal of Computer-Mediated Communication, 2007. 12(3), article 17. http://jcmc.indiana.edu/vol12/issue3/jacobs.ht $\mathrm{ml}$

Kluver, Randolf and Cheong, Pauline Hope: 'Technological Modernisation, the Internet and $\mathrm{Re}$ ligion in Singapore' Journal of Computer Mediated Education, 2007. 12(3).

http://jcmc.indiana.edu/vol12/issue3/kluver.html

Larsen, Elena: "Religion and the Internet" at MIT's Communication Forum, April $18^{\text {th }} 2002$. http://web.mit.edu/commforum/forums/religion.html).

NDTV.com (2007): http://www.ndtv.com/convergence/ndtv/story. aspx?id=NEWEN20070026005\#

Schroeder, Ralph; Heather, Noel and Raymond M. Lee: "The Sacred and the Virtual: Religion in Multi-User Virtual Reality", Journal of Computer Mediated Education 1998, 4 (2).

http://jcmc.indiana.edu/vol4/issue2/schroeder.htm I.

Sood, Gaurav: 'Spiritualism Online' The Tribune, December 25, 2000.

www.tribuneindia.com/2000/20001225/login/main 10.htm) 